\title{
Characterization of Fusarium species section Liseola by restriction analysis of the IGS region
}

\author{
M.H. Heng ${ }^{1}$, S. Baharuddin ${ }^{1}$ and Z. Latiffah ${ }^{1,2}$ \\ ${ }^{1}$ School of Biological Sciences, Universiti Sains Malaysia, \\ Pulau Pinang, Malaysia \\ ${ }^{2}$ Centre of Marine and Coastal Studies, Universiti Sains Malaysia, \\ Pulau Pinang, Malaysia \\ Corresponding author: Z. Latiffah \\ E-mail: Lfah@usm.my
}

Genet. Mol. Res. 11 (1): 383-392 (2012)

Received January 26, 2011

Accepted December 2, 2011

Published February 16, 2012

DOI http://dx.doi.org/10.4238/2012.February.16.4

\begin{abstract}
Fusarium species section Liseola namely $F$. fujikuroi, $F$. proliferatum, F. andiyazi, F. verticillioides, and F. sacchari are wellknown plant pathogens on rice, sugarcane and maize. In the present study, restriction analysis of the intergenic spacer regions (IGS) was used to characterize the five Fusarium species isolated from rice, sugarcane and maize collected from various locations in Peninsular Malaysia. From the analysis, and based on restriction patterns generated by the six restriction enzymes, Bsu151, BsuRI, EcoRI, Hin6I, HinfI, and MspI, 53 haplotypes were recorded among 74 isolates. HinfI showed the most variable restriction patterns (with 11 patterns), while EcoRI showed only three patterns. Although a high level of variation was observed, it was possible to characterize closely related species and isolates from different species. UPGMA cluster analysis showed that the isolates of Fusarium from the same species were grouped together regardless of the hosts. We conclude that restriction analysis of the IGS regions can be used to characterize Fusarium species section Liseola and to discriminate closely related species as well as to clarify their taxonomic position.
\end{abstract}

Key words: Fusarium; Intergenic spacer regions; Liseola 


\section{INTRODUCTION}

Section Liseola or Gibberella fujikuroi species complex was established by Wollenweber and Reinking (1935) in which the species in the section produced microconidia in chains as well as microconidia in false heads but did not produce chlamydospores. Snyder and Hansen (1945) adopted the name Fusarium moniliforme as the only member of the $F u$ sarium species in the section Liseola. In later studies, based on morphological characters, various workers recognized that section Liseola consisted of a number of species, from 4 to 29 (Booth, 1971; Nelson et al., 1983; Nirenberg, 1989; Nirenberg and O’Donnell, 1998). Therefore, morphological characters alone are not sufficient to identify and characterize the species of Fusarium in the section Liseola.

One of the most common methods to characterize plant pathogenic fungi is by using a combination of PCR and restriction analysis, and the region commonly used in the analysis is the intergenic spacer (IGS) of ribosomal DNA (rDNA). The IGS region has been used to differentiate fungal isolates at the intraspecific level (Hillis and Dixon, 1991; Edel et al., 1995) and to compare inter- and intraspecific variations in several species of Fusarium (Appel and Gordon, 1995; Lee et al., 2000; Hinojo et al., 2004; Konstantinova and Yli-Mattila, 2004; Llorens et al., 2006a,b; Masratul Hawa et al., 2010).

In Malaysia, studies on characterization using molecular methods of Fusarium species section Liseola are limited. In most studies, morphological characteristics and mating studies were used to identify and characterize the species (Siti Nordahliawate et al., 2008; Zainudin et al., 2008). Therefore, the objective of the present study was to characterize Fusarium species section Liseola by using restriction analysis of the IGS region.

\section{MATERIAL AND METHODS}

\section{Fungal isolates}

The Fusarium isolates used in this study are listed in Table 1. The isolates were isolated from rice, maize and sugarcane.

\section{Restriction analysis of the IGS region}

For DNA extraction, mycelia were harvested from PDA plates after 7 days of incubation at $25^{\circ} \mathrm{C}$. The DNA was extracted using a Qiagen DNeasy ${ }^{\mathbb{R}}$ Plant Mini Kit (Qiagen, USA) according to instructions provided by the manufacturer.

The IGS region was amplified using primers CNL12 (5'-CTGAACGCCTCTAAGT CAG-3') and CNS1 (5'-GAGACAAGCATATGACTACTG-3') as described by Appel and Gordon (1995). PCR amplifications were conducted in a $50-\mu \mathrm{L}$ reaction mixture containing 1X PCR buffer, $3.5 \mathrm{mM} \mathrm{MgCl}, 0.16 \mathrm{mM}$ dNTP mix, $1.75 \mathrm{U}_{2} \mathrm{GoTaq}^{\circledR}$ DNA polymerase (Promega), $0.3 \mu \mathrm{M}$ of each primers CNL12 and CNS1 and $0.35 \mu \mathrm{L}$ template DNA up to a total volume of $50 \mu \mathrm{L}$ with deionized distilled water.

PCR amplification was performed in a DNA Engine ${ }^{\mathrm{TM}}$ Peltier Thermal Cycler Model PTC- 100 with an initial denaturation at $94^{\circ} \mathrm{C}$ for 2 min followed by 35 cycles of denaturation at $94^{\circ} \mathrm{C}$ for $35 \mathrm{~s}$, annealing at $59^{\circ} \mathrm{C}$ for $55 \mathrm{~s}$ and extension at $72^{\circ} \mathrm{C}$ for $2 \mathrm{~min}$, followed by a 
final extension for $7 \mathrm{~min}$ at $72^{\circ} \mathrm{C}$. Negative controls were used to test for the presence of nonspecific reactions. The PCR product was detected on $1.5 \%$ agarose gel electrophoresis, run in Tris-borate-EDTA (TBE) buffer at $80 \mathrm{~V}$ and $400 \mathrm{~mA}$ for $100 \mathrm{~min}$. The gel was stained with ethidium bromide and visualized under a UV transilluminator. The size of the amplified IGS band was estimated by comparison to a 1-kb marker (Fermentas).

Six restriction enzymes, namely Bsu151, BsuRI, EcoRI, Hin6I, HinfI, and MspI (Fermentas), were used to digest the PCR products in a total reaction volume of $15 \mu \mathrm{L}$. The digestion procedure was according to manufacturer instructions. Digested PCR product was run on $2 \%$ agarose gel in TBE buffer for $140 \mathrm{~min}$ at $80 \mathrm{~V}$ and $400 \mathrm{~mA}$, stained with ethidium bromide and visualized on a UV transalluminator. The size of the restriction fragments was estimated and analyzed by comparison to 100-bp DNA marker (Fermentas) with the Discovery Series ${ }^{\mathrm{TM}}$ Quantity One ${ }^{\circledR}$ 1-D Analysis software, version 4.6.5.

\section{Data analysis}

Each isolate was assigned to a composite IGS haplotype defined by the combination of restriction patterns generated by the six restriction enzymes.

The Numerical Taxonomy and Multivariate Analysis System (NTSYS-pc) version 2.2 (Rohlf, 2005) was used to analyze the data. Restriction fragments produced were scored as present (1) or absent (0) for particular fragments. The binary data were then used to generate a similarity matrix using the simple matching coefficient. The similarity values obtained were then utilized to construct a dendrogram based on UPGMA cluster analysis.

In order to measure the goodness of fit of the cluster analysis to the data, a cophenetic value matrix was constructed from the dendrogram to obtain a cophenetic correlation coefficient (r) (Rohlf and Sokal, 1981), which measures the degree of correlation between the similarity matrix and the cophenetic value matrix. The $r$ value was interpreted based on Rohlf (2005) in which $\mathrm{r}>9.0$ is considered to be a very good fit and $0.8<\mathrm{r}<0.9$ is considered to be a good fit.

\section{RESULTS}

From the PCR of the IGS region using CNS and CNL primers, a single fragment of $2600 \mathrm{bp}$ was amplified from all 74 isolates of Fusarium. The PCR products were digested independently using six restriction enzymes. Depending on the isolates and the restriction enzyme, the PCR products were digested into one to six fragments. Restriction fragments of less than $100 \mathrm{bp}$ were not clearly resolved by electrophoresis. Therefore, for some of the isolates, the PCR products estimated by adding the size of the restriction fragments were less than the size of the undigested PCR products. Three to 11 restriction patterns were generated by the six restriction enzymes. HinfI showed the most variable patterns with 11 patterns followed by Hin61 and MspI with nine patterns. BsuRI produced eight patterns and Bsu151 produced four patterns. Figure 1 shows the restriction patterns produced using Hin61. The least variable patterns were generated by EcoRI with three patterns (Figure 2). Isolates of F. fujikuroi showed the same restriction patterns as HinfI and MspI, and isolates of $F$. verticillioides produced the same $B s u$ RI restriction patterns. 


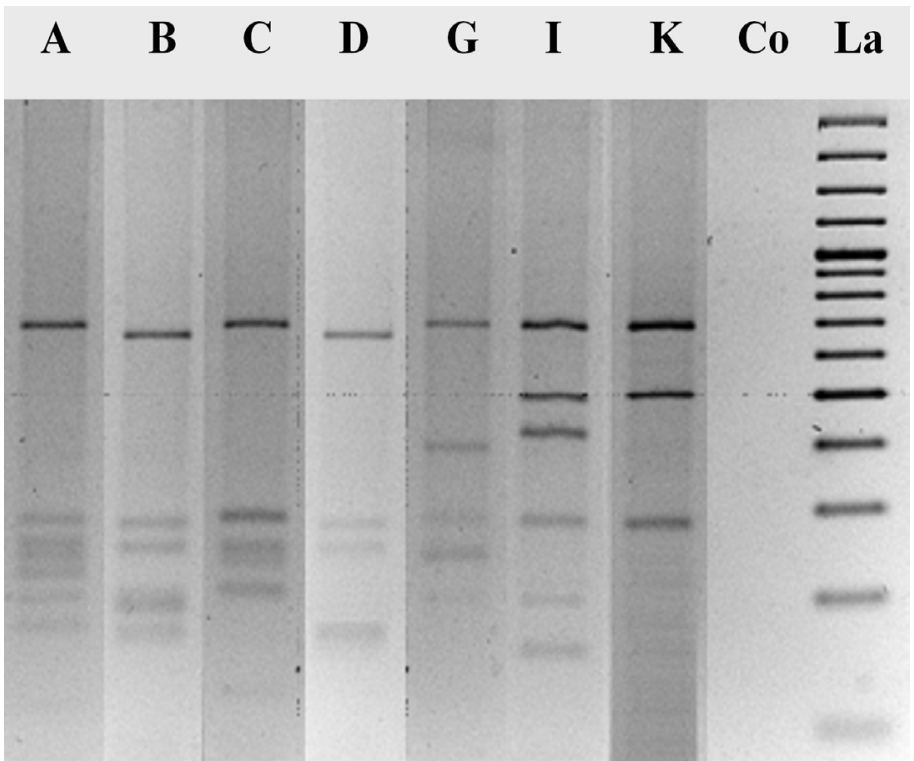

Figure 1. Restriction patterns obtained after digestion with HinfI. Lane $A=3067$ (Fusarium fujikuroi); lane B= $\mathrm{JB} 2(F$. verticillioides $)$; lane $C=\mathrm{B} 1(F$. verticillioides $)$; lane $D=3055(F$. andiyazi); lane $G=\mathrm{P} 4(F$. proliferatum $)$; lane $I=3081$ (F. sacchari); lane $K=\mathrm{T} 9$ (F. sacchari); lane Co = control; lane La=100-bp DNA marker.

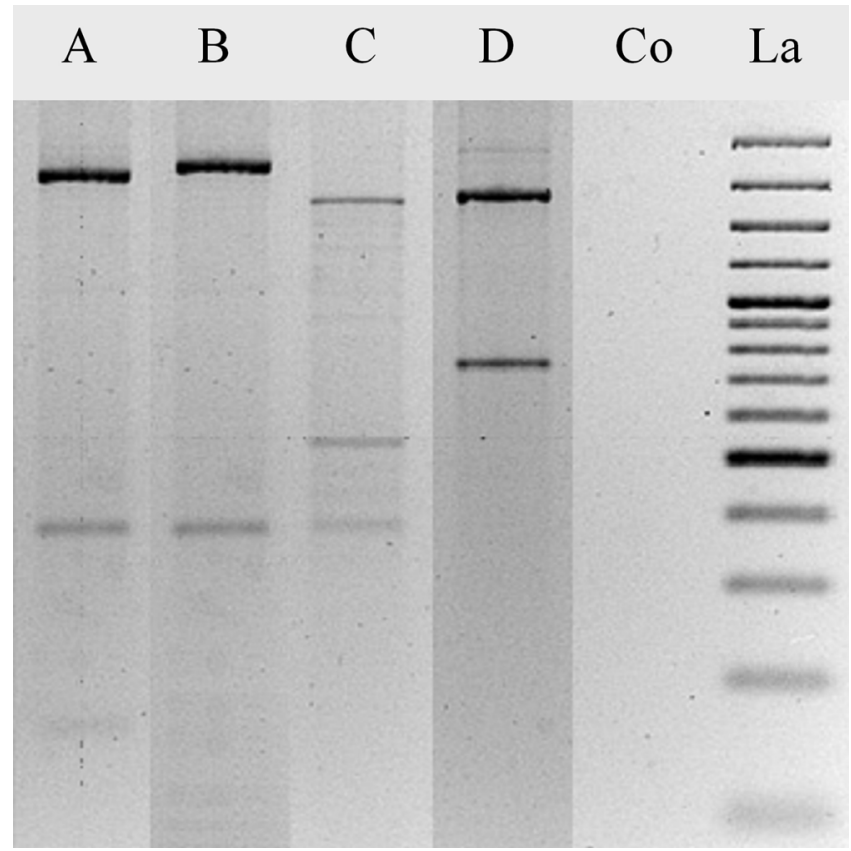

Figure 2. Restriction patterns obtained after digestion with EcoRI. Lane $A=3308$ (Fusarium sacchari); lane B= T4 (F. sacchari); lane $C=\mathrm{B} 2$ ( $F$. verticillioides); lane $D=3055$ (F. andiyazi); lane Co = control; lane La = 100-bp DNA marker. 
Based on restriction patterns generated by the six restriction enzymes, 53 haplotypes were recorded among 74 isolates (Table 1). In general, none of the haplotypes assigned were shared between different species except for two isolates of $F$. proliferatum (3151 and 3170) and one isolate of F. fujikuroi (3122), which shared the same haplotype. Haplotypes 1-7 were assigned to isolates of $F$. fujikuroi, haplotypes 8-13 to F. proliferatum, haplotypes 14-17 to $F$. andiyazi, haplotypes 18-31 to $F$. verticillioides, and haplotypes 32-53 to isolates of $F$. sacchari.

Table 1. Fusarium isolates used in this study and the haplotypes generated by using restriction analysis of the IGS region among the isolates of Fusarium spp section Liseola.

\begin{tabular}{|c|c|c|c|c|c|c|c|c|}
\hline \multirow[t]{2}{*}{ Host/isolate } & \multirow[t]{2}{*}{ Species } & \multicolumn{6}{|c|}{ Restriction patterns } & \multirow[t]{2}{*}{ Haplotype } \\
\hline & & Bsu15I & $B s u$ RI & EcoRI & Hin6I & HinfI & MspI & \\
\hline $0621(\mathrm{R})$ & F. fujikuroi & A & A & $\mathrm{A}$ & $\mathrm{A}$ & $\mathrm{A}$ & $\mathrm{A}$ & 1 \\
\hline $3132(\mathrm{R})$ & F. fujikuroi & $\mathrm{A}$ & $\mathrm{A}$ & $\mathrm{A}$ & $\mathrm{A}$ & $\mathrm{A}$ & $\mathrm{A}$ & 1 \\
\hline 3067 (R) & F. fujikuroi & $\mathrm{A}$ & $\mathrm{A}$ & $\mathrm{B}$ & A & A & A & 2 \\
\hline 3099 (R) & F. fujikuroi & A & $\mathrm{A}$ & $\mathrm{B}$ & A & A & A & 2 \\
\hline $3101(\mathrm{R})$ & F. fujikuroi & A & $\mathrm{B}$ & $\mathrm{A}$ & I & A & A & 3 \\
\hline 3105 (R) & F. fujikuroi & $\mathrm{A}$ & $\mathrm{B}$ & $\mathrm{C}$ & $\mathrm{A}$ & A & A & 4 \\
\hline $3208(\mathrm{R})$ & F. fujikuroi & $\mathrm{A}$ & $\mathrm{E}$ & B & A & $\mathrm{A}$ & A & 5 \\
\hline $3122(\mathrm{R})$ & F. fujikuroi & $\mathrm{D}$ & $\mathrm{B}$ & $\mathrm{B}$ & $\mathrm{A}$ & A & A & 6 \\
\hline JF5 (M) & F. fujikuroi & $\mathrm{D}$ & A & $\mathrm{A}$ & A & A & A & 7 \\
\hline $\mathrm{P} 4(\mathrm{R})$ & F. proliferatum & $\mathrm{A}$ & $\mathrm{A}$ & $\mathrm{B}$ & $\mathrm{F}$ & G & $\mathrm{H}$ & 8 \\
\hline $3074(\mathrm{R})$ & F. proliferatum & A & G & B & $\mathrm{D}$ & $\mathrm{H}$ & G & 9 \\
\hline 3075 (R) & F. proliferatum & A & G & $\mathrm{B}$ & $\mathrm{D}$ & $\mathrm{H}$ & G & 9 \\
\hline 3151 (R) & F. proliferatum & $\mathrm{D}$ & $\mathrm{B}$ & $\mathrm{B}$ & $\mathrm{A}$ & $\mathrm{A}$ & $\mathrm{A}$ & 6 \\
\hline $3170(\mathrm{R})$ & F. proliferatum & $\mathrm{D}$ & $\mathrm{B}$ & $\mathrm{B}$ & $\mathrm{A}$ & A & A & 6 \\
\hline $\mathrm{P} 1(\mathrm{R})$ & F. proliferatum & $\mathrm{D}$ & G & $\mathrm{B}$ & $\mathrm{D}$ & $\mathrm{H}$ & $\mathrm{H}$ & 10 \\
\hline P2 (R) & F. proliferatum & $\mathrm{D}$ & G & $\mathrm{B}$ & $\mathrm{D}$ & $\mathrm{H}$ & $\mathrm{H}$ & 10 \\
\hline 3095 (R) & F. proliferatum & $\mathrm{D}$ & $\mathrm{A}$ & B & $\mathrm{D}$ & $\mathrm{H}$ & $\mathrm{D}$ & 11 \\
\hline 3238 (SC) & F. proliferatum & A & $\mathrm{E}$ & $\mathrm{C}$ & I & G & I & 12 \\
\hline 3324 (SC) & F. proliferatum & $\mathrm{A}$ & $\mathrm{E}$ & $\mathrm{C}$ & $\mathrm{H}$ & G & I & 13 \\
\hline $3055(\mathrm{R})$ & F. andiyazi & $\mathrm{C}$ & $\mathrm{E}$ & B & $\mathrm{C}$ & $\mathrm{C}$ & $\mathrm{D}$ & 14 \\
\hline $3061(\mathrm{R})$ & F. andiyazi & $\mathrm{C}$ & $\mathrm{E}$ & B & $\mathrm{C}$ & $\mathrm{C}$ & $\mathrm{D}$ & 14 \\
\hline $3086(\mathrm{R})$ & F. andiyazi & $\mathrm{C}$ & $\mathrm{E}$ & $\mathrm{B}$ & $\mathrm{C}$ & $\mathrm{C}$ & $\mathrm{D}$ & 14 \\
\hline 3073 (R) & F. andiyazi & $\mathrm{D}$ & $\mathrm{G}$ & $\mathrm{C}$ & $\mathrm{F}$ & $\mathrm{C}$ & A & 15 \\
\hline 3088 (R) & F. andiyazi & $\mathrm{D}$ & $\mathrm{E}$ & $\mathrm{B}$ & $\mathrm{C}$ & $\mathrm{C}$ & $\mathrm{D}$ & 16 \\
\hline $3137(\mathrm{R})$ & F. andiyazi & $\mathrm{C}$ & $\mathrm{E}$ & $\mathrm{B}$ & I & $\mathrm{C}$ & $\mathrm{E}$ & 17 \\
\hline $\mathrm{T} 1$ (SC) & F. verticillioides & $\mathrm{C}$ & $\mathrm{C}$ & $\mathrm{C}$ & $\mathrm{E}$ & $\mathrm{D}$ & $\mathrm{C}$ & 18 \\
\hline JB1 (M) & F. verticillioides & $\mathrm{C}$ & $\mathrm{C}$ & $\mathrm{C}$ & $\mathrm{E}$ & $\mathrm{D}$ & $\mathrm{C}$ & 18 \\
\hline $\mathrm{B} 1(\mathrm{M})$ & $F$ verticillioides & $\mathrm{C}$ & $\mathrm{C}$ & $\mathrm{C}$ & $\mathrm{E}$ & $\mathrm{D}$ & $\mathrm{C}$ & 18 \\
\hline JB4 (M) & F. verticillioides & $\mathrm{C}$ & $\mathrm{C}$ & $\mathrm{C}$ & $\mathrm{E}$ & $\mathrm{D}$ & $\mathrm{C}$ & 18 \\
\hline B2 (M) & F. verticillioides & $\mathrm{C}$ & $\mathrm{C}$ & $\mathrm{C}$ & $\mathrm{E}$ & $\mathrm{B}$ & $\mathrm{B}$ & 19 \\
\hline B3 (M) & $F$ verticillioides & $\mathrm{C}$ & $\mathrm{C}$ & $\mathrm{C}$ & $\mathrm{E}$ & $\mathrm{B}$ & $\mathrm{B}$ & 19 \\
\hline B5 (M) & F. verticillioides & $\mathrm{C}$ & $\mathrm{C}$ & $\mathrm{C}$ & $\mathrm{E}$ & $\mathrm{B}$ & $\mathrm{B}$ & 19 \\
\hline B6 (M) & F. verticillioides & $\mathrm{C}$ & $\mathrm{C}$ & $\mathrm{C}$ & $\mathrm{E}$ & B & B & 19 \\
\hline B9 (M) & F. verticillioides & $\mathrm{C}$ & $\mathrm{C}$ & $\mathrm{C}$ & $\mathrm{E}$ & B & B & 19 \\
\hline JB2 (M) & $F$ verticillioides & $\mathrm{C}$ & $\mathrm{C}$ & $\mathrm{C}$ & $\mathrm{E}$ & $\mathrm{B}$ & $\mathrm{B}$ & 19 \\
\hline JD4 (M) & $F$ verticillioides & $\mathrm{C}$ & $\mathrm{C}$ & $\mathrm{C}$ & $\mathrm{E}$ & $\mathrm{B}$ & $\mathrm{B}$ & 19 \\
\hline $3124(\mathrm{R})$ & $F$. verticillioides & $\mathrm{C}$ & $\mathrm{C}$ & $\mathrm{C}$ & $\mathrm{E}$ & $\mathrm{B}$ & $\mathrm{B}$ & 19 \\
\hline JF1 (M) & F. verticillioides & $\mathrm{C}$ & $\mathrm{C}$ & $\mathrm{C}$ & $\mathrm{E}$ & $\mathrm{B}$ & $\mathrm{C}$ & 20 \\
\hline B4 (M) & $F$ verticillioides & $\mathrm{C}$ & $\mathrm{C}$ & $\mathrm{C}$ & $\mathrm{E}$ & $\mathrm{B}$ & $\mathrm{E}$ & 21 \\
\hline F1 (M) & $F$ verticillioides & $\mathrm{C}$ & $\mathrm{C}$ & $\mathrm{C}$ & $\mathrm{E}$ & $\mathrm{A}$ & $\mathrm{A}$ & 22 \\
\hline 3257 (SC) & F. verticillioides & $\mathrm{C}$ & $\mathrm{C}$ & $\mathrm{C}$ & B & $\mathrm{K}$ & $\mathrm{E}$ & 23 \\
\hline 3277 (SC) & F. verticillioides & $\mathrm{C}$ & $\mathrm{C}$ & $\mathrm{C}$ & $\mathrm{B}$ & $\mathrm{B}$ & $\mathrm{B}$ & 24 \\
\hline $\mathrm{T} 2(\mathrm{SC})$ & $F$. verticillioides & $\mathrm{C}$ & $\mathrm{C}$ & $\mathrm{C}$ & $\mathrm{E}$ & $\mathrm{D}$ & B & 26 \\
\hline $0654(\mathrm{R})$ & F. verticillioides & $\mathrm{C}$ & $\mathrm{C}$ & $\mathrm{C}$ & $\mathrm{B}$ & $\mathrm{B}$ & $\mathrm{C}$ & 27 \\
\hline $3063(\mathrm{R})$ & F. verticillioides & $\mathrm{C}$ & $\mathrm{C}$ & $\mathrm{B}$ & $\mathrm{B}$ & $\mathrm{B}$ & $\mathrm{D}$ & 28 \\
\hline T5 (SC) & F. verticillioides & $\mathrm{D}$ & $\mathrm{C}$ & $\mathrm{B}$ & $\mathrm{E}$ & $\mathrm{D}$ & $\mathrm{D}$ & 29 \\
\hline $3068(\mathrm{R})$ & F. verticillioides & $\mathrm{D}$ & $\mathrm{C}$ & $\mathrm{C}$ & $\mathrm{B}$ & $\mathrm{C}$ & A & 30 \\
\hline JB3 (M) & F. verticillioides & $\mathrm{D}$ & $\mathrm{C}$ & $\mathrm{C}$ & $\mathrm{E}$ & $\mathrm{B}$ & $\mathrm{B}$ & 31 \\
\hline
\end{tabular}

Continued on next page 


\begin{tabular}{|c|c|c|c|c|c|c|c|c|}
\hline \multirow[t]{2}{*}{ Host/Isolate } & \multirow[t]{2}{*}{ Species } & \multicolumn{6}{|c|}{ Restriction patterns } & \multirow[t]{2}{*}{ Haplotype } \\
\hline & & Bsu15I & $B s u \mathrm{RI}$ & EcoRI & $\operatorname{Hin} 6 \mathrm{I}$ & HinfI & $M s p \mathrm{I}$ & \\
\hline $3054(\mathrm{R})$ & F. sacchari & $\mathrm{C}$ & $\mathrm{F}$ & $\mathrm{B}$ & G & $\mathrm{C}$ & $\mathrm{D}$ & 32 \\
\hline $3078(\mathrm{R})$ & F. sacchari & $\mathrm{C}$ & $\mathrm{H}$ & $\mathrm{B}$ & G & $\mathrm{E}$ & $\mathrm{F}$ & 33 \\
\hline 3081 (R) & F. sacchari & A & $\mathrm{H}$ & $\mathrm{B}$ & $\mathrm{H}$ & I & $\mathrm{E}$ & 34 \\
\hline 3327 (SC) & F. sacchari & $\mathrm{A}$ & $\mathrm{H}$ & B & $\mathrm{H}$ & G & $\mathrm{F}$ & 35 \\
\hline 3343 (SC) & F. sacchari & $\mathrm{A}$ & $\mathrm{H}$ & $\mathrm{B}$ & $\mathrm{H}$ & $\mathrm{F}$ & $\mathrm{F}$ & 35 \\
\hline 3350 (SC) & F. sacchari & A & $\mathrm{D}$ & $\mathrm{A}$ & $\mathrm{H}$ & I & $\mathrm{G}$ & 36 \\
\hline 3358 (SC) & F. sacchari & $\mathrm{A}$ & $\mathrm{D}$ & $\mathrm{A}$ & $\mathrm{H}$ & J & $\mathrm{C}$ & 37 \\
\hline 3308 (SC) & F. sacchari & $\mathrm{A}$ & $\mathrm{D}$ & $\mathrm{A}$ & $\mathrm{H}$ & $\mathrm{J}$ & $\mathrm{C}$ & 37 \\
\hline $\mathrm{T} 8$ (SC) & F. sacchari & A & $\mathrm{D}$ & $\mathrm{B}$ & $\mathrm{H}$ & $\mathrm{J}$ & $\mathrm{C}$ & 37 \\
\hline T6 (SC) & F. sacchari & A & $\mathrm{H}$ & $\mathrm{B}$ & $\mathrm{H}$ & $\mathrm{J}$ & G & 38 \\
\hline 3281 (SC) & F. sacchari & A & $\mathrm{H}$ & $\mathrm{B}$ & $\mathrm{H}$ & $\mathrm{J}$ & $\mathrm{G}$ & 38 \\
\hline $3082(\mathrm{R})$ & F. sacchari & $\mathrm{B}$ & $\mathrm{H}$ & $\mathrm{B}$ & $\mathrm{H}$ & $\mathrm{J}$ & $\mathrm{F}$ & 39 \\
\hline $3087(\mathrm{R})$ & F. sacchari & $\mathrm{B}$ & $\mathrm{H}$ & $\mathrm{B}$ & $\mathrm{H}$ & I & $\mathrm{D}$ & 41 \\
\hline B10 & F. sacchari & B & $\mathrm{D}$ & $\mathrm{A}$ & $\mathrm{H}$ & I & $\mathrm{C}$ & 42 \\
\hline 3084 (R) & F. sacchari & $\mathrm{C}$ & $\mathrm{F}$ & B & G & E & $\mathrm{F}$ & 43 \\
\hline 3246 (SC) & F. sacchari & $\mathrm{C}$ & $\mathrm{F}$ & B & $\mathrm{G}$ & $\mathrm{F}$ & $\mathrm{F}$ & 44 \\
\hline 3262 (SC) & F. sacchari & $\mathrm{C}$ & G & $\mathrm{A}$ & G & $\mathrm{F}$ & $\mathrm{F}$ & 45 \\
\hline 3310 (SC) & F. sacchari & $\mathrm{C}$ & $\mathrm{G}$ & $\mathrm{A}$ & G & F & $\mathrm{F}$ & 45 \\
\hline $\mathrm{T} 4(\mathrm{SC})$ & F. sacchari & $\mathrm{C}$ & $\mathrm{D}$ & B & G & $\mathrm{F}$ & $\mathrm{F}$ & 46 \\
\hline T9 (SC) & F. sacchari & $\mathrm{C}$ & $\mathrm{D}$ & $\mathrm{A}$ & $\mathrm{H}$ & E & $\mathrm{F}$ & 47 \\
\hline $3295(\mathrm{SC})$ & F. sacchari & $\mathrm{C}$ & $\mathrm{F}$ & $\mathrm{B}$ & I & $\mathrm{F}$ & $\mathrm{F}$ & 48 \\
\hline 3349 (SC) & F. sacchari & $\mathrm{C}$ & $\mathrm{F}$ & B & D & $\mathrm{E}$ & $\mathrm{F}$ & 49 \\
\hline P5 (R) & F. sacchari & $\mathrm{D}$ & $\mathrm{H}$ & B & $\mathrm{H}$ & $\mathrm{J}$ & G & 50 \\
\hline F2 (M) & F. sacchari & $\mathrm{D}$ & D & A & G & $\mathrm{J}$ & $\mathrm{F}$ & 51 \\
\hline T7 (SC) & F. sacchari & $\mathrm{D}$ & $\mathrm{D}$ & B & $\mathrm{H}$ & $\mathrm{J}$ & $\mathrm{C}$ & 52 \\
\hline $\mathrm{T} 3$ (SC) & F. sacchari & $\mathrm{D}$ & $\mathrm{D}$ & $\mathrm{B}$ & $\mathrm{H}$ & $\mathrm{J}$ & $\mathrm{F}$ & 53 \\
\hline
\end{tabular}

Since highly variable restriction patterns were generated by the six restriction enzymes and the isolates were divided into different haplotypes, UPGMA cluster analysis was performed to group the isolates and to estimate the levels of intra- and interspecies variability among the isolates.

The dendrogram constructed from the similarity matrix using UPGMA cluster analysis is presented in Figure 3. The cophenetic correlation coefficient (r) obtained was 0.91, which indicated a good fit between the cluster analysis and the data. Based on the dendrogram, the isolates from the same species were clustered in the same cluster and the grouping of the isolates can be divided into two major clusters, 1 and 2, and several sub-clusters (Figure 3).

Major cluster 1 consisted of isolates from four species, namely F. fujikuroi, F. verticillioides, F. proliferatum, and $F$. andiyazi. Although, F. fujikuroi and $F$. proliferatum are reported to be sibling species, both species produced different haplotypes except for isolate 3122 (F. fujikuroi), 3151 (F. proliferatum) and 3170 (F. proliferatum), which shared the same haplotype. Isolates of $F$. sacchari and five isolates of $F$. proliferatum were grouped in major cluster 2.

Isolates of $F$. fujikuroi were grouped in sub-cluster $1 \mathrm{~A}$ with a similarity value of $82-100 \%$. Sub-clusters $1 \mathrm{C}$ and $2 \mathrm{~B}$ consisted of isolates of $F$. proliferatum. Isolates of $F$. verticillioides and six isolates of $F$. andiyazi formed sub-cluster $1 \mathrm{~B}$ with similarity values ranging from $73-100 \%$. Isolates of $F$. sacchari were clustered in sub-cluster $2 \mathrm{~A}$ with 72 $100 \%$ similarity. 


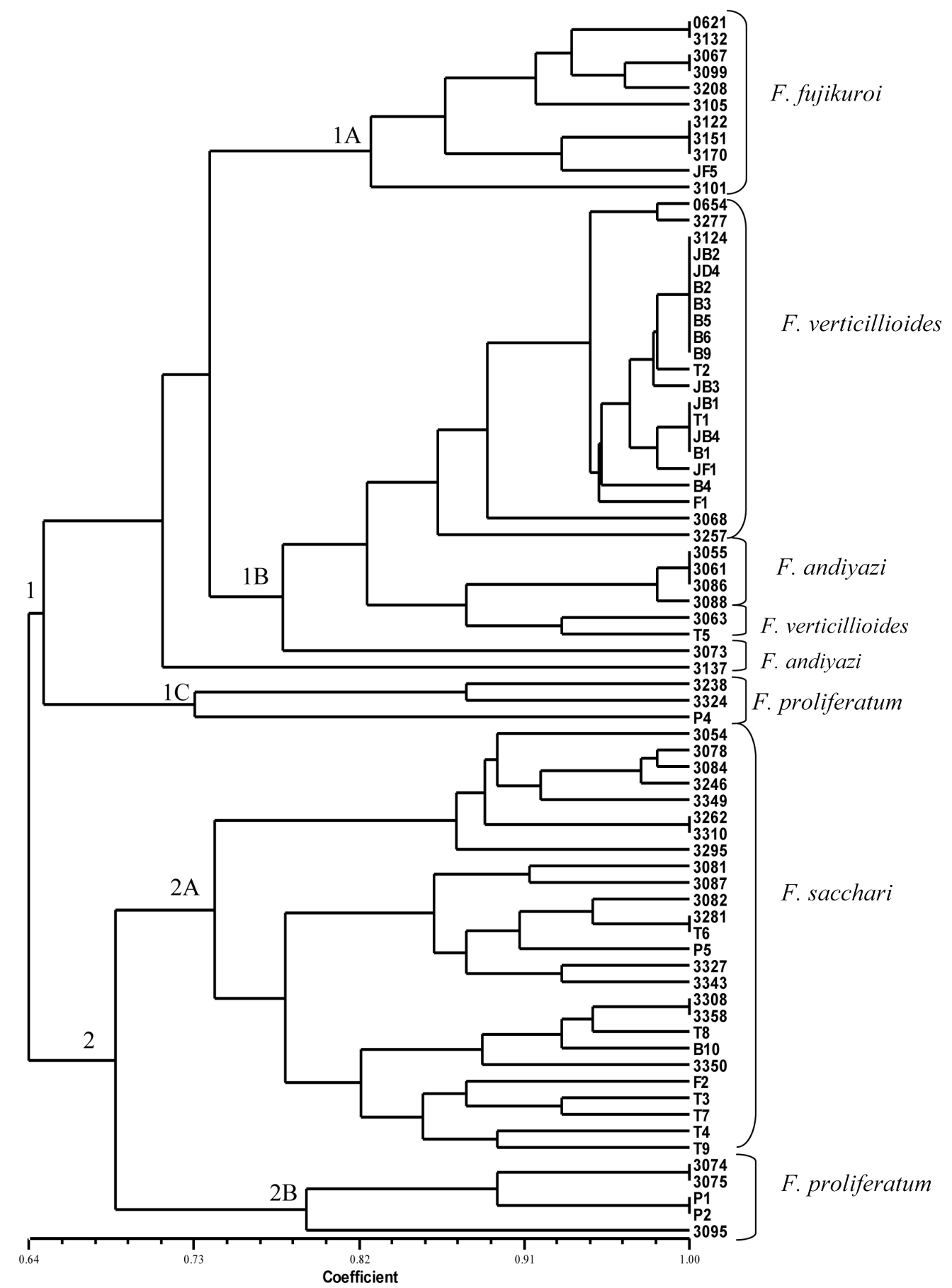

Figure 3. Dendrogram generated using UPGMA cluster analysis based on restriction fragments of the IGS region. 


\section{DISCUSSION}

A single fragment of 2600 bp was amplified from all the 74 isolates of Fusarium spp, which was similar to the results obtained from several studies of Fusarium spp in which the size of the IGS region varied from 2200 to 2600 bp (Konstantinova and Yli-Mattila, 2004; Patino et al., 2006; Llorens et al., 2006a,b).

Among the six restriction enzymes used in this study to digest the PCR products, HinfI showed the most variable restriction patterns with 11 patterns while EcoRI produced only three patterns. In general, the restriction patterns produced by the isolates of Fusarium spp showed highly variable restriction patterns. The high levels of variability of the IGS region could be due to insertions or deletions in the arrays of sub-repeat units within the IGS region and unequal cross-over, which indicated that this region might be evolving intensively (Coen et al., 1982; Hillis and Davis, 1988).

High levels of inter- and intraspecific variability were also observed among the five Fusarium species as indicated by different haplotypes produced by different restriction enzymes. The results obtained were similar to findings by Patino et al. (2006), in which intraspecific variability was detected within the $F$. verticillioides species complex based on PCR-RFLP of the IGS region using seven restriction enzymes and a study from Hinojo et al. (2004) on G. fujikuroi isolates from pine, maize and banana fruits. Edel et al. (1996) also found that the intraspecific variability of Fusarium spp was greater than interspecific variability using PCRRFLP analysis of rDNA with eight restriction enzymes.

The high degree of intraspecific variability could also be caused by species complex in which the species in section Liseola are grouped in the Gibberella fujikuroi species complex. The species complex consisted of sexual stage or Gibberella teleomorph, which has been found in F. fujikuroi, F. proliferatum, F. verticillioides, and F. sacchari.

As the isolates of Fusarium spp showed variable restriction patterns, UPGMA cluster analysis was performed to cluster the isolates and estimate the intra- and interspecific variability. From UPGMA cluster analysis based on the restriction bands, most of the isolates of Fusarium spp from the same species were generally clustered in the same cluster. The restriction patterns and the haplotypes obtained did not show any correlation to the host.

From the present study, although a high level of variation was observed, the variations were found to be sufficient to characterize closely related species and isolates from different species. Isolates from the same species produced similar haplotypes and isolates from different species did not produce the same haplotype except for an isolate of F. fujikuroi (3122) and two isolates of $F$. proliferatum $(3151,3170)$. The most variable restriction patterns were shown by isolates of $F$. sacchari followed by isolates of $F$. verticillioides. However, for both species, the number of isolates was higher than the number of isolates for the other species.

Isolates of F. fujikuroi and F. proliferatum were grouped in separate clusters. Both species are very closely related and are regarded as sibling species (Leslie et al., 2007). Moreover, both teleomorphs ( $G$. fujikuroi and $G$. intermedia) have been reported to be interfertile (Leslie et al., 2004). In the present study, isolates of F. fujikuroi can be differentiated from isolates of F. proliferatum based on HinfI and MspI patterns in which the restriction patterns of HinfI and MspI produced by isolates of $F$. fujikuroi were different from isolates of $F$. proliferatum. In Malaysia, F. fujikuroi is commonly associated with bakanae disease on rice and $F$. proliferatum has a wide host range, infecting various agricultural crops, such as rice, asparagus and 
maize. The variability shown by isolates of $F$. proliferatum was similar to a study by Edel et al. (1996) using restriction analysis of the internal transcribed spacer region.

Although isolates of $F$. verticillioides and $F$. andiyazi were clustered in the same subcluster (sub-cluster 1B), the restriction patterns and the haplotypes produced by both species were different. Morphological characters of both species are very similar but $F$. andiyazi produced pseudochlamydospore instead of chlamydospore (Marasas et al., 2001). F. andiyazi has been isolated from sorghum (Marasas et al., 2001) and rice seed (Wulff et al., 2010), whereas F. verticillioides is widely distributed worldwide and causes various types of diseases on a wide host range, including maize and rice.

Isolates of $F$. sacchari were grouped together and showed variable restriction patterns, but the haplotypes produced were different from the other Fusarium species. Fusarium sacchari was the most common species associated with pokkah boeng disease of sugarcane (Gerlach and Nirenberg, 1982; Egan et al., 1997) and the species has been isolated from maize and rice in Malaysia.

The results of the present study showed that restriction analysis of the IGS region can be used to characterize Fusarium species section Liseola as the technique was found to allow discrimination of closely related species. The technique can also be used to assign new isolates to a species or closely related species as well as to clarify their taxonomic position.

\section{ACKNOWLEDGMENTS}

Research supported by the Fundamental Research Grant Scheme (\#203/PBIOLOGY/ 671057), Ministry of Higher Education, Malaysia.

\section{REFERENCES}

Appel DJ and Gordon TR (1995). Intraspecific variation within populations of Fusarium oxysporum based on RFLP analysis of the intergenic spacer region of the rDNA. Exp. Mycol. 19: 120-128.

Booth C (1971). The Genus Fusarium. Commonwealth Agricultural Bureau, Bucks.

Coen ES, Thoday JM and Dover G (1982). Rate of turnover of structural variants in the rDNA gene family of Drosophila melanogaster. Nature 295: 564-568.

Edel V, Steinberg C, Avelange I, Laguerre G, et al. (1995). Comparison of three molecular methods for the characterization of Fusarium oxysporum strains. Phytopathology 85: 579-585.

Edel V, Steinberg C, Gautheron N and Alabouvette C (1996). Evaluation of restriction analysis of polymerase chain reaction (PCR)-amplified ribosomal DNA for the identification of Fusarium species. Mycol. Res. 101: 179-187.

Egan BT, Magarey RC and Croft BJ (1997). Sugarcane. In: Soilborne Diseases of Tropical Crops (Hillocks RJ and Walker JM, eds.). CAB International, Wallingford, 277-302.

Gerlach W and Nirenberg H (1982). The Genus Fusarium - A Pictorial Atlas. Mitteilungen aus der Bioloischen Bundesansalt für Land-und Forstwirschaft, Berlin-Dahlem.

Hillis DM and Davis SK (1988). Ribosomal DNA: intraspecific polymorphism, concerted evolution and phylogeny reconstruction. Syst. Biol. 37: 63-66.

Hillis DM and Dixon MT (1991). Ribosomal DNA: molecular evolution and phylogenetic inference. Q. Rev. Biol. 66: 411-453.

Hinojo MJ, Llorens A, Mateo R, Patino B, et al. (2004). Utility of the polymerase chain reaction-restriction fragment length polymorphisms of the intergenic spacer region of the rDNA for characterizing Gibberella fujikuroi isolates. Syst. Appl. Microbiol. 27: 681-688.

Konstantinova P and Yli-Mattila T (2004). IGS-RFLP analysis and development of molecular markers for identification of Fusarium poae, Fusarium langsethiae, Fusarium sporotrichioides and Fusarium kyushuense. Int. J. Food Microbiol. 95: 321-331.

Lee YM, Choi YK and Min BR (2000). PCR-RFLP and sequence analysis of the rDNA ITS region in the Fusarium spp. 
J. Microbiol. 38: 66-73.

Leslie JF, Zeller KA, Wohler M and Summerell BA (2004). Interfertility of two mating populations in the Gibberella fujikuroi species complex. Eur. J. Plant Pathol. 110: 611-618.

Leslie JF, Anderson LL, Bowden RL and Lee YW (2007). Inter- and intra-specific genetic variation in Fusarium. Int. J. Food Microbiol. 119: 25-32.

Llorens A, Hinojo MJ, Mateo R, Gonzalez-Jaen MT, et al. (2006a). Characterization of Fusarium spp. isolates by PCRRFLP analysis of the intergenic spacer region of the rRNA gene (rDNA). Int. J. Food Microbiol. 106: 297-306.

Llorens A, Hinojo MJ, Mateo R, Medina A, et al. (2006b). Variability and characterization of mycotoxin-producing Fusarium spp isolates by PCR-RFLP analysis of the IGS-rDNA region. Antonie Van Leeuwenhoek 89: 465-478.

Marasas WFO, Rheeder JP, Lamprecht SC and Zeller KA (2001). Fusarium andiyazi sp. nov., a new species from sorghum. Mycologia 93: 1203-1210.

Masratul Hawa M, Salleh B and Latiffah Z (2010). Characterization and intraspecific variation of Fusarium semitectum (Berkeley and Ravenel) associated with red-fleshed dragon fruit (Hylocereus polyrhizus [Weber] Britton and Rose) in Malaysia. Afr. J. Biotechnol. 9: 273-284.

Nelson PE, Toussoun TA and Cook RJ (1983). Fusarium Species. An Illustrated Manual for Identification. The Pennsylvania State University Press, University Park and London, London.

Nirenberg HI (1989). Identification of Fusaria Occurring in Europe on Cereals and Potatoes. In: Fusarium: Mycotoxins, Taxonomy and Pathogenicity (Chelkowski J, ed.). Elsevier Science Publishers B.V., Amsterdam, 179-193.

Nirenberg HI and O'Donnell K (1998). New Fusarium species and combinations within the Gibberella fujikuroi species complex. Mycologia 90: 434-458.

Patino B, Mirete S, Vazquez C, Jimenez M, et al. (2006). Characterization of Fusarium verticillioides strains by PCRRFLP analysis of the intergenic spacer region of the rDNA. J. Sci. Food Agric. 86: 429-435.

Rohlf FJ (2005). NTSYS-pc Numerical Taxonomy and Multivariate Analysis System Version 2.2. Exeter Publication, New York.

Rohlf FJ and Sokal RR (1981). Comparing numerical taxonomic studies. Syst. Zool. 30: 459-490.

Siti Nordahliawate MS, Nur Ain Izzati MZ, Azmi AR and Salleh B (2008). Distribution, morphological characterization and pathogenicity of Fusarium sacchari associated with pokkah boeng disease of sugarcane in Peninsula Malaysia. Pertanika J. Trop. Agric. Sci. 31: 279-286.

Snyder WC and Hansen HN (1945). The species concept in Fusarium with reference to discolor and other sections. Am. J. Bot. 32: 657.

Wollenweber HW and Reinking OA (1935). Die Fusarien, ihre Beschreibung, Schadwirkung und Bekampfung. Verlag Paul Parey, Berlin.

Wulff EG, Sorensen JL, Lubeck M, Nielsen KF, et al. (2010). Fusarium spp. associated with rice Bakanae: ecology, genetic diversity, pathogenicity and toxigenicity. Environ. Microbiol. 12: 649-657.

Zainudin NAIN, Razak AA and Salleh B (2008). Bakanae disease of rice in Malaysia and Indonesia: etiology of the causal agent based on morphological, physiological and pathogenicity characteristics. J. Plant Prot. Res. 48: 475-485. 